\title{
Linking Circular Economy and Sustainable Energy Technology through Quintuple Helix Perspective
}

\author{
Waznatol Widad Mohamad Ishak ${ }^{1}$, Siti Indati Mustapa ${ }^{1}$, Norsyahida Mohammad', \\ Azlina Mohamad Jais ${ }^{2}$ \\ ${ }^{1}$ Institute of Energy Policy and Research, Universiti Tenaga National, Malaysia \\ ${ }^{2}$ Energy Commission, Malaysia
}

\begin{abstract}
Sustainable energy development was signified as the global energy transition pathways that drive essential changes in how energy is being generated, transmitted, and consumed. The concept of Circular Economy (CE) has been proposed to address the environmental problem by minimizing the resource inputs and emission generation, reusing the waste, and refusing the conventional production process to obtain further benefit. However, the contribution of CE to sustainable energy development and its link to Quintuple Helix (QH) elements is still ambiguous. This paper intends to fulfil this gap by examining the five main elements of the $\mathrm{QH}$ that contribute to the CE ecosystem, namely academia, companies, environment, government, and society. Innovative technologies from sludge management in urban wastewater sectors are discussed as the case study. A framework relating the QH with CE and innovation are proposed for future research. Practical recommendations associated with CE and sustainable energy policies are also provided.
\end{abstract}

Keywords: Circular Economy; Sustainable Energy; Energy Transition; Quintuple Helix; Waste-toEnergy

\section{INTRODUCTION}

The establishment of sustainable energy remains a crucial challenge globally. As civilization continues to be driven by exploiting natural resources for energy generation, energy sustainability is regarded as a necessity to maintain economic growth and prosperity. Access to clean, affordable, and reliable energy has been a foundation to create energy transformation that requires a thorough interpretation. According to the United Nations (UN), sustainability is defined as "meeting the needs of the present without compromising the ability of future generations to meet their own needs" (United Nations Brundtland Commission, 1987). That means sustainable energy can be described as inexhaustible energy whereby the sources renewed rather than left depleted while being harmless toward the environment. The global energy demand had shown remarkable rises, and the majority still relied on fossil fuel resources. However, a recent report by International Energy Agency (IEA) in 2019 stated that global energy demand had declined below the average rate due to sluggish global economic growth, which is caused by the unprecedented COVID-19 pandemic (IEA, 2019b). In the meantime, the energy demand is eventually expected to rise post-pandemic to meet the needs mainly from industries and households. Therefore, sustainable energy systems are crucial to meet future energy demands while reducing undesirable impacts on the environment. For instance, the industrial sector has been incentivized to opt

Corresponding author

Waznatol Widad Mohamad Ishak, waznatol.widad@gmail.com; Siti Indati Mustapa, indati@uniten.edu.my; Norsyahida Mohammad, norsyahida_mohammad@yahoo.co.uk; Mohamad Jais, azlinamj@st.gov.my 
for renewable energy (RE) and energy efficiency technology to reduce their cost by lowering the demand for coal and fossil fuels.

Furthermore, global carbon dioxide (CO2) and other greenhouse gases (GHG) emissions should be reduced to combat climate change. The integration of RE resources and the emphasis on energy efficiency in power generation played a massive role in reducing carbon emission (IEA, 2019a). Besides, the transition towards zero-carbon energy systems via decarbonization is also considered in attaining sustainable energy technology. Sustainable energy technology comprises four main categories: sustainable energy economics and management, RE generation and consumption, environmental impacts of energy systems, and electric vehicle and energy storage (Chen et al., 2019). A robust strategy is required to boost sustainable energy transition across these four categories. For example, the transition of the transportation sector towards sustainability requires innovation of transportation technology and energy usage. The assessment of transition pathways in the European Union's (EU) transportation sector (Dominković et al., 2018) revealed that electric vehicles have more potential than biofuel vehicles. However, the advantages of the electric vehicle may be jeopardized if the electricity used to electric power vehicles is generated from fossil fuels. Energy production methods need to be alleviated from conventional approaches to a more sustainable manner. Thus, the penetration of this transition either in technology or economic aspect could turn further discussion and potential alternatives.

Recently, the circular economy (CE) concept has gained considerable popularity. The concept presented strong linkages between the environment and economic activities in evaluating the viability of a process. In Turkey, the CE concept conducted has revealed that, as the country focuses on solar energy as a primary electricity source, greater attention is needed to ensure sustainable solar photovoltaic (PV) waste management (Erat and Telli, 2020). Another study in India revealed that penetration of the CE principle enhances the country's sustainable economic development, especially in the integration of RE and advancement in the waste management sector (Ellen MacArthur Foundation (EMF), 2016). Overall, the application of the CE concept demonstrated a positive effect on sustainable energy technology. Previous studies related to sustainable energy technology have been focusing on utilizing RE resources, energy efficiency, and technological innovation for power generation (Chel and Kaushik, 2018; Qazi et al., 2019; Lu et al., 2020). However, there is a gap in linking the CE concept and sustainable energy technology via the Quintuple Helix $(\mathrm{QH})$ perspective. The $\mathrm{QH}$ elements enable broader perspectives in achieving sustainable energy technology, facilitating further improvement in implemented policies. Therefore, this paper aims to provide a systematic view of CE and sustainable energy technology from the QH nexus. A theoretical framework utilizing the $\mathrm{QH}$ perspective would be developed. A case study in the wastewater sector is included to investigate QH's roles: the government, industry, academia, society, and environment. The initiatives and practical recommendations associated with sustainable energy technology and CE concept are provided, focusing on improving waste management and energy policies.

\section{LITERATURE REVIEW}

\section{A Quintuple Helix: A Framework for Circular Economy (CE) and Sustainable Energy}

The Quintuple Helix framework is utilized to identify the interaction between selected elements toward the body of knowledge. Historically, the framework has been developed based on the Triple Helix framework theorized by Henry Etzkowitz and Loet Leydesdorff in the 1990s (Etzkowitz and Leydesdorff, 1995). The Triple Helix framework has been employed to discuss the relationship between the university, 
industry, and the government toward several subjects such as innovation, policy development, economic concept, and business strategy (Galvao et al., 2019). The collaboration of the university, industry and government in the Triple Helix framework had resulted in effective and efficient innovation in sustainability development (Galvao et al., 2019; Luengo-Valderrey et al., 2020). The culture of innovation has been rigorously studied. However, emerging technology and business transition unreasonably fit the needs of society and the environment. Therefore, the Triple Helix framework was extended to Quadruple Helix and Quintuple Helix by adding society and the natural environment as the new elements in 2009 and 2010 (Carayannis and Campbell, 2010). The society element gives a reasonable interpretation of public understanding and media exploitation where it perceives innovation in dynamic experiences (Carayannis and Campbell, 2009; Carayannis, Barth and Campbell, 2012; Grundel and Dahlström, 2016). The natural environment of society has been identified as a spur for production and innovation because it would create synergies between the economy, society, and democracy. The socioecological focuses on interaction, codevelopment, and co-evolution of culture and nature (Carayannis and Campbell, 2010; Carayannis, Barth and Campbell, 2012). Quintuple Helix, as shown in Figure 1 below, has been claimed to support open innovation and has the potential to be a framework for the transdisciplinary analysis of sustainable development and social ecology by connecting the environment element in the subject of innovation and knowledge (Carayannis, Barth and Campbell, 2012). Even though several scholars had surfaced numerous criticisms toward the concept, such as on how to clearly define the public and environment, whether they are a real different element nor extension of the previous element, (Leydesdorff, 2012) countered that Triple Helix could be extended algorithmically to an N-tuple of helices while (Höglund and Linton, 2018) agreed that social element is a different type of helix despite the other three helixes being discussed. Drawing upon this, it looks like more researchers could contribute to exploring the challenges of the Quintuple Helix from the point of view of sustainable innovation.

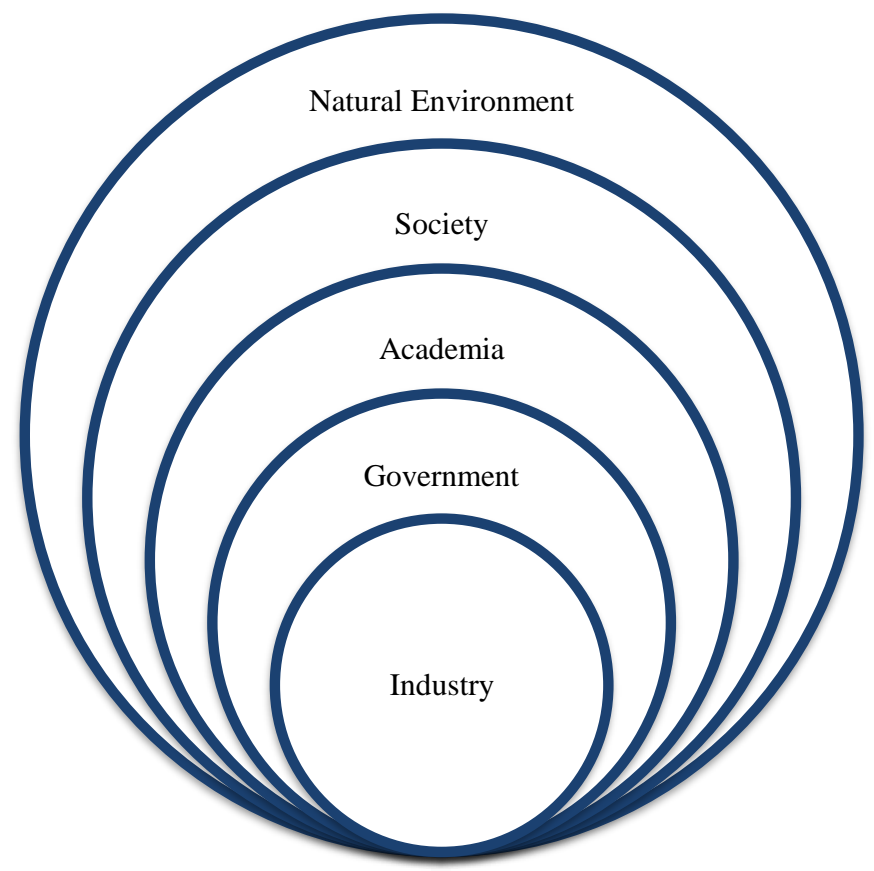

Figure 1: Quintuple Helix Model

Source: Adapted from (Carayannis, Barth and Campbell, 2012) 
Sustainable energy technology is defined as a high-efficiency energy system consisting of sustainable energy resources that are well-managed to balance environmental and social costs, risks, and benefits (Chen et al., 2019). Components of sustainable energy technology include clean energy generation, transmission, and distribution, storage of chemical and electrical energy, energy efficiency, and smart and efficient energy management systems (Chu et al., 2017). The sustainable energy concept has shifted a global paradigm toward how the industry, society, and government- play a role in energy generation, transmission, and consumption. For instance, through simple changes in people's behaviour, energy usage and waste generation could be lowered tremendously. An industry or a firm that engage in a good sustainable practice can result in decreasing the operation cost and preserving the environment via emission reduction. In a study to examine the relevancy of the Triple Helix as drivers in sustainable innovation, (Luengo-Valderrey et al., 2020) found that the Triple Helix concept has a positive and significant impact on the firm. Thus, recognizing the Triple Helix strategy is very valuable. As for the power sector, understanding how to minimize resource scarcity and organization of the supply chain enables establishing a comprehensive plan to generate sound output in the long term (Melkonyan et al., 2017). Another study had applied the Quadruple and Quintuple Helixes models in the initiative of innovative specialization strategies and smart sustainability in the European Union (Carayannis and Rakhmatullin, 2014).

On the other hand, the $\mathrm{CE}$ is defined as an industrial system that is restorative and regenerative by intention and design (MacArthur and Ellen, 2013). The CE enables the establishment of sustainable energy technology. For instance, the waste from industry is utilized as feedstock for another sector, also known as the waste-to-energy system. As established by the European Union Council in 1999, efficient waste management highlights the waste order of priority starting from prevention, reuse, recycling, energy recovery, and disposal (Lausselet et al., 2017). The clean energy produced from RE resources, including organic waste and technological advancements in energy generation such as power-to-gas technology, hydrogen energy, and fuel cells, is crucial in achieving sustainable energy technology via the CE concept. Therefore, the Quintuple Helix model comprises five main elements: government, industry, academia, society, and environment have an essential role in connecting the CE and sustainable energy technology. The government is responsible for creating an ecosystem that enhances sustainability in the country's energy system, including policies, regulations, subsidies, preferential tax treatments, and trade restrictions (Pan et al., 2015). These initiatives would then assist energy-related industries in shifting to cleaner energy resources for power generation and enabling competitive electricity pricing for consumers.

In the realization of CE, a life-cycle assessment (LCA) of the waste to energy system is frequently conducted. The review enables the identification of environmental impacts and cost-competitiveness of every stage of the life cycle. The LCA is usually performed by the academic helix, assisted by industries related to the product or services. The LCA conducted and reviewed in the literature provides various perceptions of waste-to-energy processes, including combustion, gasification, and anaerobic digestion. Waste from agricultural and industrial sectors and solid municipal wastes are utilized to produce energy into biochar, green fuel pellet, bio-gas, and heat or electricity to power industries (Pan et al., 2015). This sustainable energy linkages support the CE system where the consumption of primary energy sources is reduced, waste is prevented, or otherwise recycled. Every initiative in the transition towards a CE from a linear economy requires support from another basic helix: the environment. Although CE drives the shift towards sustainable energy technology, it is evident that the help of the citizen is of its utmost importance, while environmental concerns itself plays a vital role in alleviating the cooperation of citizens. 
Likewise, technological advancements and innovations usually became the products of integrating QH in sustainable energy technology strategy assisted by CE. The technical aspect is an essential output from the academic helix, brought to realization by the citizen helix, which could be observed as the recent advancements in the energy sector and urban planning revolve around creating smart grids and smart cities. A study on ASEAN Smart Cities Network utilizing the QH model reveals that although smart cities technology produces more manageable cities, the outcome works against the interest in sustainability (Crumpton et al., 2020). Smart cities are claimed to be complex, while a paradigm shift must support smart cities development in ASEAN member states. Therefore, sustainable energy technology is facilitated by technological advancements driven by $\mathrm{CE}$, which requires a thorough analysis via $\mathrm{QH}$ to drive the participation of multiple stakeholders associated with sustainable energy technology. As shown in Figure 2 below, the proposed framework summarised the inter-relationship between each of the five QH element (i.e., government, industry, academia, society, and environment) and CE through the sustainable technology approaches.

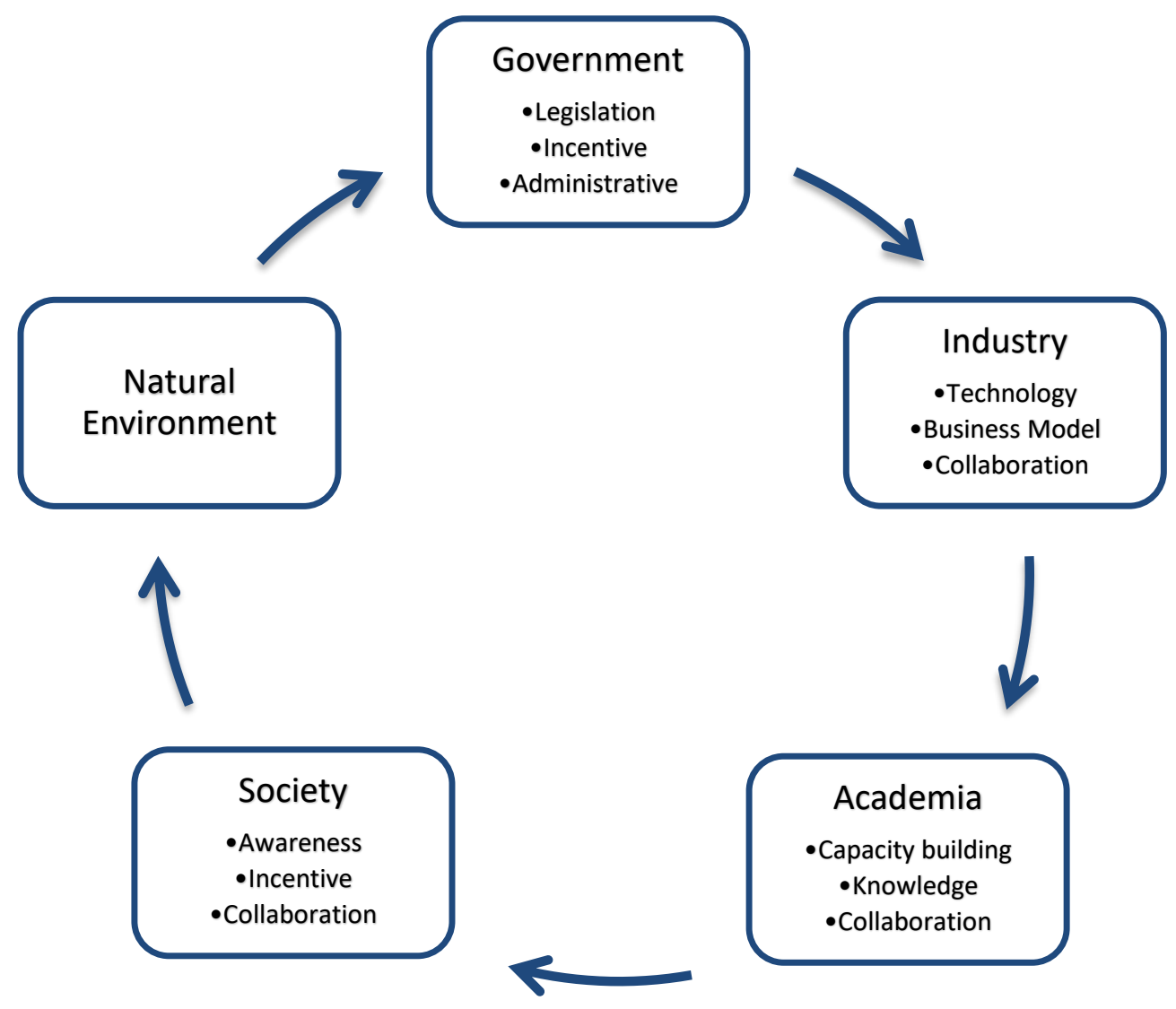

Figure 2: Framework of CE and Sustainable Energy Technology through Quintuple Helix. Source: Adapted from (Carayannis, Barth and Campbell, 2012; Durán-Romero et al., 2020)

\section{Current Practises of CE Ecosystem and Sustainable Energy Technology}

South Korea faces environmental resource limitations, and currently, $84 \%$ of the energy supply contribute from fossil-based sources (Stoev, 2018). The increase in greenhouse gas (GHG) emission, the growing population, and the rapid development of Korea's manufacturing industries have caused huge climate change that will damage up to $20 \%$ of global GDP without appropriate mitigation actions (Stern, 
2006). Therefore, it needs to deploy intensive action in addressing the impact through a new paradigm of the linear economic model with a circular approach. Since the linear approach has been successful in Korea for decades, the circular economic model aims to use fewer resources through efficient processes, waste prevention, reuse, repair, remanufacture, and recycling. According to OECD, South Korea had the second highest recycling rate country in OECD countries in 2013 (McCarthy, 2016). Therefore, the Korean Ministry of Environment (MOE) has announced and enacted the principle of resource circulation as a concrete action to transit into a circular wave (Ministry of Environment, 2017). The resource circulation strategies include National Strategy for Green Growth, Resource Efficiency Programme (REP), Recycling Technology Programme (RTP) and Energy Recovery Programme (ERP) to increase the demand and supply of energy from waste. In other words, the principle contains policies to reduce waste in all processes, including production, distribution, consumption, and disposal of products, and promote recycling.

From the perspective of the wastewater and sewerage industry, which consumes extensive energy, Korea's government faces tremendous pressure to have independent and sustainable energy and reduce the operation cost (Kangyin et al., 2016). Therefore, this particular industry can be a crucial part of circular sustainability due to the integration of energy production such as biogas and small hydropower and resource recoveries like nutrient retrieval and clean water (Neczaj and Grosser, 2018). Taking the Korean government as an example, it has a good track record in integrated waste management. It has been proved by the high number of small business and external markets related to waste, reduction of landfill space, and cheap public services (OECD, 2017). On the other hand, the modernization of sewerage and wastewater system in Korea subsequently led by a virtuous designated policy and the intuitional measure had resulted in a global leader in the water and wastewater services, pollution and water-borne diseases as well as energy independency system (Danilenko and Bahuguna, 2016; Ministry of Environment, 2017). Table 1 below shows the summary of the relationship of the quintuple helix (QH) toward CE and sustainable energy technology.

Table 1: Summary of Quintuple Helix Capacity: A Case Study from South Korea.

\begin{tabular}{|c|c|}
\hline Main Drivers & Approaches \\
\hline Industry & $\begin{array}{l}\text { Advance technology, product development, and environmental concern are } \\
\text { the major driving factors triggering Korea's industry. Monitoring and studying } \\
\text { a new method in the technological aspect could lead to improvement } \\
\text { measures and increase the system's reliability. Additionally, the long-term } \\
\text { strategy also would be based on the project cost. Thus, carefully select and } \\
\text { install the technology suitable for the industry and sufficiently verified by the } \\
\text { regulator had secure enough to exercise a sound system. }\end{array}$ \\
\hline
\end{tabular}

Government The Ministry prepares laws, standards, guidelines, and regulations. The local authority, private partnership, and public jointly collaborated in improving the policy and strategy. The private partnership making water a more attractive investment opportunity under the Build, Own, Operate, and Transfer (BOOT) mechanism. Most policies in Korea are set up by establishing long-term goals 
Journal of Governance Risk Management Compliance and Sustainability (JGRCS), Vol. 1 (1), 07-25

Linking Circular Economy and Sustainable Energy Technology through Quintuple Helix Perspective

Waznatol Widad Mohamad Ishak, Siti Indati Mustapa, Norsyahida Mohammad, Azlina Mohamad Jais

\begin{tabular}{ll} 
Main Drivers & Approaches \\
\hline & to ensure consistency in arising the services and other indirect social and \\
environmental impact. & \\
& $\begin{array}{l}\text { Funding is mainly made up of national budgetary and expenses. In some cases, } \\
\text { allocation may be carried out as private investment projects. The federal } \\
\text { budget that supports the project is ensured to follow the standard project cost } \\
\text { analyzed by the government, whereby this is to certify that the relevant } \\
\text { criteria are met when designing. }\end{array}$
\end{tabular}

\begin{tabular}{ll}
\hline Academia & Experts from private companies, universities, government-sponsored \\
& institutions, and research institutes have collaborated and built partnerships \\
& for consultation and deliberation of significant policies and technical advice. \\
& Additionally, engagement with society will be done to reflect the opinions of \\
& residents.
\end{tabular}

Society The decision on technology intervention is based on economic efficiency, treatment stability, domestic performance, and public corporations certified by the Ministry. Improving awareness is vital for selecting facilities with the right technology and evaluate its impact on society.

Environment The direct effect of the technology and system is to improve the environment, which is periodically analyzed through the total pollution management system. The environmental technology development project is specified in Article 5 of the Environmental Technology and Environmental Projects Supporting Act to be promoted by national and public research institutes, government agencies, research institutes, and industrial technology expert.

Source: Author's elaboration based on questionnaire feedback during a benchmarking visit to South Korea.

On the other hand, in Sweden, the annual energy use is around 600TWh, and the sources are from four leading carriers: oil, nuclear power, biofuels, and hydropower. Almost $80 \%$ of fossil fuels are used in the transport sector. However, currently, Sweden has been shifted the focus to use the produced biogas in the transportation sector as vehicle gas. Based on the study done by (Swedish Gas Technology Ltd, 2012), 1.4TWh of biogas is produced annually in Sweden from approximately 230 facilities. Half of the biogas production is contributed by 135 wastewater treatment plants. Since the landfilling of organic waste has been banned in 2005, the sludges in wastewater are converted to biogas and show an extreme reduction of biogas produced in landfills. There is an immense potential for sustainable resources in Sweden, and essential technologies are changing rapidly. As a country with strong environmental policies, access to a large amount of domestic natural resources, and a growing population, the priorities of developing a new business model and a sustainable system is paramount. Policy intervention in promoting CE models is needed by educating the public with CE knowledge, allowing cross-collaboration to enable infrastructure 
development, and transforming from waste management to resource management approaches (Westblom, 2015).

Urban infrastructure and inefficient resource management are among the factor caused an increase of around 50\% in climate emission and more than $90 \%$ of the world's water scarcities and biodiversity deficiencies (Ministry of Environment and Ministry of Enterprise and Innovation, 2020). In Sweden, the CE strategy focused on toxin-free and eco-cycle, business sector, and services area. Besides, the world-class Swedish companies featured with skilled innovators who enable production and deliverable resources portray a solid aspiration for focus on a fossil-free society (Swedish Enterprise, 2019). Nevertheless, the industry structure in Sweden is energy-intensive. The majority of the total energy use in industrial is embedded in high cost and government budgetary. However, the process of adopting innovative technology is a crucial agenda in developing a sustainable system. According to a study done by (Bergquist and Söderholm, 2016), the finding showed despite developing policy in sustainable energy by emphasizing knowledge and cross-sector collaboration. The government should also improve the existing policy, especially the implementation of energy taxes and fee. Doing this shows the government's ability to push the industrial sector to embark on new and sustainable technology. Even though (Bergquist and Söderholm, 2016) had analyzed the transition towards RE and increased energy efficiency in the Swedish pulp and paper industry only. Still, it gives a bigger picture of the Swedish energy policy and the energy transition direction. Another study pointed out that the supply section in energy policy has been overlooked, especially in governing the municipalities. Traditionally, the municipalities act as a supplier of gas, electricity, and heating facilities (Palm, 2006). Therefore, the policy seems to be an essential indication to embark on the energy transition. With the cooperation from cross-sector and industry, implementing the CE approach and developing sustainable energy technology could meet current increasing energy demand and conserve the environment.

While in Malaysia, sustainable energy development vigorously concentrated in two areas which are adapting the RE and improving current energy efficiency (Shafie et al., 2011). The establishment of the National Renewable Energy Policy and Action Plan (NREPAP) in 2008, the National Energy Efficiency Action Plan (NEEAP) in 2015, and the Sustainable Energy Development Authority (SEDA) played an essential role in strengthening the action without leaving the importance of environmental protection. A new paradigm of the CE concept has been practised in several industries to support a low carbon economy (Khor and Lalchand, 2014). The constitutional framework, industrial management, energy cycle consumption, and wastewater and sludge usage have significantly influenced the implemented CE system in Pengerang Integrated Petroleum Complex (PIPC) (Hishammuddin et al., 2018). However, the engagement with QH, such as the technology availability in the industry, awareness of the society, and feasibility of other stakeholders and authority bodies, must be addressed to understand the impact of the implemented initiative. As a blessed country with abundant natural resources supported by several compromised sectors in producing the raw material for power generation, Malaysia strived to provide more clean energy. The residue from crops like palm oil, paddy, and rubber has a vast potential to be used as fuel for electricity generation using the cogeneration system (Mokhtar, 2002; Shafie et al., 2011). Recently, Malaysia has actively developed a Circular Economy Roadmap to solve several issues such as unsystematic waste management and unutilized resource (Asia-Pacific Economic Cooperation, 2020). This roadmap urged to achieve zero single-use plastic by 2030 and 
embrace the new eco-friendly alternative by practising the CE system (Ministry of Energy, Science, Technology, Environment \& Climate Change, 2018). Table 2 below summarise the key drivers, challenges, and priorities of the three countries discussed relating to the CE and sustainable energy technology.

Table 2: Literature Review on Adaptation of CE and Sustainable Energy Technology

\begin{tabular}{|c|c|c|c|}
\hline Country & Korea & Sweden & Malaysia \\
\hline $\begin{array}{l}\text { Key } \\
\text { Drivers }\end{array}$ & $\begin{array}{l}\text { Climate change } \\
\text { Retarded of natural } \\
\text { resource } \\
\text { Rapid urbanization }\end{array}$ & $\begin{array}{l}\text { Systematic structure } \\
\text { Climate Change } \\
\text { Pollution }\end{array}$ & $\begin{array}{l}\text { Abundant raw material } \\
\text { Agriculture and } \\
\text { manufacturing dominated }\end{array}$ \\
\hline Challenges & $\begin{array}{l}\text { Ensuring sustainable } \\
\text { financing in invested } \\
\text { technology. } \\
\text { Weak cooperation among } \\
\text { ministries and society on } \\
\text { environmental issues had } \\
\text { caused GHG emission to } \\
\text { increase rapidly. }\end{array}$ & $\begin{array}{l}\text { Global climate change } \\
\text { appears to be pushing the } \\
\text { European climate towards } \\
\text { more extreme seasonal } \\
\text { variations with more } \\
\text { droughts in the dry seasons } \\
\text { and more floods in the wet } \\
\text { season, calling for more } \\
\text { robust resource } \\
\text { management. }\end{array}$ & $\begin{array}{l}\text { Lacking in policy and } \\
\text { regulation enforcement. } \\
\text { The high cost of investment } \\
\text { in sustainable technology. } \\
\text { Low rate of awareness and } \\
\text { acceptance level among } \\
\text { society. }\end{array}$ \\
\hline Priorities & $\begin{array}{l}\text { Energy \& Water recovery } \\
\text { Climate recovery } \\
\text { Environmental-friendly } \\
\text { technology }\end{array}$ & $\begin{array}{l}\text { Urban Environment } \\
\text { Resource recovery } \\
\text { Climate recovery }\end{array}$ & $\begin{array}{l}\text { Energy recovery } \\
\text { Energy efficiency } \\
\text { Waste recovery }\end{array}$ \\
\hline Outlook & $\begin{array}{l}\text { Support government } \\
\text { approach related } \\
\text { resource management } \\
\text { using the circular model. } \\
\text { Pursue greater } \\
\text { cooperation among } \\
\text { sectors and establish a } \\
\text { reliable information } \\
\text { system. }\end{array}$ & $\begin{array}{l}\text { Increase environmental } \\
\text { awareness and monitoring } \\
\text { ecological status. } \\
\text { Emphasize regulatory } \\
\text { framework. } \\
\text { Continuing to improve and } \\
\text { support innovation and } \\
\text { technology advancement to } \\
\text { mitigate sustainable } \\
\text { development. }\end{array}$ & $\begin{array}{l}\text { Highlight a circular } \\
\text { approach to explore the } \\
\text { potential resource that can } \\
\text { be regenerated. } \\
\text { Develop collaboration with } \\
\text { potential industry to } \\
\text { establish sustainable energy } \\
\text { technology. } \\
\text { Strengthen policy and } \\
\text { regulation on resource }\end{array}$ \\
\hline
\end{tabular}


Journal of Governance Risk Management Compliance and Sustainability (JGRCS), Vol. 1 (1), 07-25

Linking Circular Economy and Sustainable Energy Technology through Quintuple Helix Perspective

Waznatol Widad Mohamad Ishak, Siti Indati Mustapa, Norsyahida Mohammad, Azlina Mohamad Jais

\begin{tabular}{|c|c|c|c|}
\hline Country & Korea & Sweden & Malaysia \\
\hline & $\begin{array}{l}\text { Strengthen policy and } \\
\text { regulation in line with } \\
\text { the sustainable } \\
\text { development agenda. }\end{array}$ & & $\begin{array}{l}\text { recovery and technology } \\
\text { efficiency. }\end{array}$ \\
\hline Advantage & $\begin{array}{l}\text { Fast economic growth } \\
\text { High energy } \\
\text { consumption } \\
\text { Manufacturing } \\
\text { technology }\end{array}$ & $\begin{array}{l}\text { Long term exposure to } \\
\text { advance technology } \\
\text { Fast-growing urban city }\end{array}$ & $\begin{array}{l}\text { Modest economic growth in } \\
\text { ASEAN } \\
\text { Abundant of potential } \\
\text { resource }\end{array}$ \\
\hline Reference & $\begin{array}{l}\text { (Jin, 2016; Lopes } \\
\text { de Sousa Jabbour et al., } \\
\text { 2018; Hong et al., 2019; } \\
\text { Landsberger, 2019; } \\
\text { Herrador, Cho and Park, } \\
\text { 2020; Nam, Hwangbo } \\
\text { and Yoo, 2020) }\end{array}$ & $\begin{array}{l}\text { (Ek, 2005; Assefa and } \\
\text { Frostell, 2007; Swedish } \\
\text { Environmental Protection } \\
\text { Agency, 2008; Westblom, } \\
\text { 2015; Wijkman and } \\
\text { Skånberg, 2015) }\end{array}$ & $\begin{array}{l}\text { (Mohd Din, 2010; Shafie et } \\
\text { al., 2011; Palanisamy K. and } \\
\text { Shamsuddin A.H., 2013; } \\
\text { Akademi Sains Malaysia, } \\
\text { 2015; Ramli and Abdul } \\
\text { Hamid, 2016; } \\
\text { Hishammuddin et al., 2018; } \\
\text { Abdullah et al., 2019) }\end{array}$ \\
\hline
\end{tabular}

\section{RESEARCH METHOD}

In this study, a qualitative method from a primary data source is used. Field observation and a questionnaire were conducted for data collection. The choice of this method to be employed was affected by the ease of data standardization, representativeness, time constraints, cost and type of information needed. In comparing questionnaires and interview, it is relatively easy to arrange a questionnaire survey. Two sets of questionnaires in the form of a case study are developed to distribute among the related wastewater treatment facilities. For the case study, we select a few designated wastewater facilities in Malaysia and South Korea based on the size of the plant, technology used, facilities' availability, policy development and governance to be a part of this research study. A mailed questionnaire was used in a descriptive and auditing formatted and not as an analytical cause-effect construct.

Furthermore, in supporting further our findings, this study also benefits from a vast range of data gathered from various valid references. All the supporting evidence extracted from (Mohd Din, 2010; Abbas et al., 2011; Abd, Wan and Presenter, 2011; Tuan Mat, Shaari and Kok How, 2011; Rebitanim et al., 2013; Akademi Sains Malaysia, 2015; Kumaran, 2016; Ellen MacArthur Foundation (EMF), 2016; Esa, Halog and Rigamonti, 2017; Mustapa, 2018; Sabeen et al., 2018; Carayannis et al., 2018; Hishammuddin et al., 2018; Hanum et al., 2019; IEA, 2019b; Priyadarshini and Abhilash, 2020; Durán-Romero et al., 2020). 


\section{FINDINGS AND DISCUSSION}

\section{Application of CE in the Wastewater Sector in Malaysia}

The sustainability agenda is practised in every sector such as agricultural, business, and waste management, including wastewater services. Integrating CE into the business chains is to optimize resource usage (raw materials) and minimize wastage from production and emissions, as shown in Figure 3. The national sewerage company in Malaysia, prominently known as Indah Water Konsortium (IWK), had the initiative to adopt this CE model approach and exploring potential application for the wastewater treatment by-product. The three by-products are clean water (effluent), biosolids (sludge), and methane released by the wastewater treatment process. This initiative framework to reuse the by-products seems promising in mitigating some of the current cost pressures at the IWK. They are a lot of potential for reusing the by-product of wastewater, as mention by IWK. For instance, IWK's entire operation had produced between 5,000 to 6,000 million litres per day (MLD) of clean water. However, regulation has prohibited the channelling of effluent directly back into the water supply system. In terms of biosolid byproduct, it has been reported that 120,000 tonnes of sludge are produced by IWK's treatment plants nationwide annually. The sewage sludge is commonly disposed of either at the landfill and trenching sites or burned in incinerators, which is not good for the environment. It may still contain contaminants that remain as ash and contribute to crucial concern among the service providers and consumers.

On the other hand, IWK could generate up to 2,400 MWh by harnessing all the potential methane from its 6745 plants nationwide. On average, a plant could consume electricity of 43,503 kWh/day, equivalent to $40 \%$ of the overall operation and maintenance cost. Therefore, generating power through biogas from anaerobic digestion could help reduce the plant's total energy consumption and sold to neighbouring households. However, the challenge in realizing this initiative is that the IWK plants are too scattered, small, and not transportable for such a plan to be viable. Nevertheless, as the third-largest consumer of energy in ASEAN, the dependent on conventional resources and environmental issues gained the attention of the government and researchers to investigate the RE coming from bioenergy sources. Sludge management has been opted to be a case study to explore the circularity concept on the sewage sludge in Malaysia. This case study framed the role in driving sustainable energy within the $\mathrm{QH}$ perspective: industry, government, society, academia, and natural environment.

In the industrial ecosystem, the creation and dissemination of sustainable energy technology have been based on firms' initiative but limited by governmental regulation. In this case, wastewater operators have the responsibility of providing public services to the local communities. However, maintaining and sustaining the sector with the ageing, malfunction, and failing infrastructure and inefficient technology becomes an enormous challenge. Thus, an industry player is suggested to adopt an innovative approach for sustainable growth and develop environmentally-friendly technology that reduces $\mathrm{CO} 2$ emission and increased firm revenue (Carayannis, Barth and Campbell, 2012). Meanwhile, (Carayannis, Barth and Campbell, 2012) stated that the government is a part of the political system in the helix chain. The government should give support in terms of incentive and funding associated with comprehensive regulations and policies in initiating the sustainable transition. Policy setting such as $20 \%$ RE including biogas in the energy mix by 2025, $100 \%$ sludge to be recycled by $2030,60 \%$ installation of rainwater harvesting system by 2020 , and recycled one-third of treated effluent by 2030 , would enable the country's transitions towards a green economy.

On the other hand, the academia helix plays a crucial role as the promoter in changing the understanding and connecting the gap between knowledge and practicality. Litardi, Fiorani and Bara, 2020 found that education has a strong relationship in research application and leading the involvement 
of various entities will strengthen productivity and creating shared value. Therefore, establishing a research and development (R\&D) and technical training centre in the wastewater sector creates an opportunity to build collaboration with academia. A few partnerships towards green growth have been initiated successfully. For instance, a biogas and micro-hydropower plant project collaborated between IWK's R\&D centre and Universiti Tenaga Nasional (May Lim et al., 2013). Continuous improvement projects have been an annual program to encourage a culture of innovation throughout the operation.

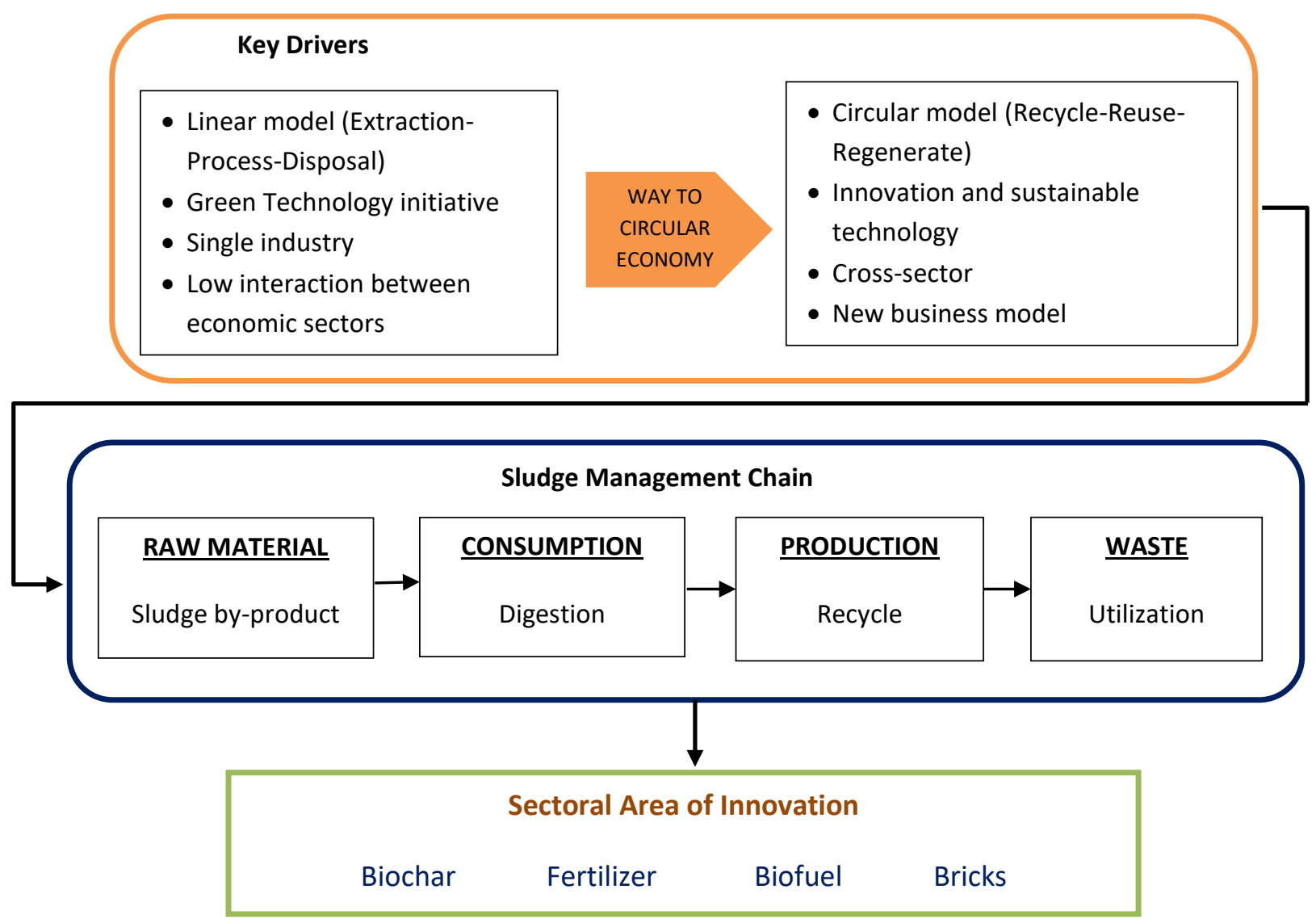

Figure 3: CE Model for Sludge Management.

Source: Adopted from (Durán-Romero et al., 2020)

Public awareness and acceptance of the importance of the sewerage system have increased over the past years due to the development of fingertip technology and accessible media. Various initiatives to educate and raise awareness among society has been accomplished. For example, Program Indah Alam by IWK aimed to inform the importance of desludging individual septic tank, and the Greater Kuala Lumpur project focused on the rehabilitation of 4the public sewer network. The demand for a cleaner environment and the need for environmental protection has driven sustainable technology in the wastewater sector. However, this improvement will consume colossal investment, and the current sewerage tariff still low. Promoting the public to pay more on sewerage bills could cause public objection. Therefore, the prolongation of the awareness program is a good initiative. This process helps the industry to include public concern, experiences, and preferences in its decision-making (W Muhammad Abdullah et al., 2021).

Furthermore, the symbiosis of CE's knowledge and sustainable energy technology innovation is expected to be cleared by adding the natural environment perspective. This interactive system can support 
the development of the wastewater sector in Malaysia (Harwiki and Malet, 2020). The extraction of a resource from nature and making it become a product or service will have an economic value (Korhonen, Honkasalo and Seppälä, 2018). For instance, wastewater is viewed not as waste but rather as a valuable non-conventional resource that should be circulated to sustain scarce life-essential resources that benefited both economic and environmental aspect (Lettinga, Lens and Zeeman, 2001; Werner et al., 2003). Several studies broaden the perspective of the QH by examining the role of collaboration. This sustainable transition requires efforts from all the institutional helix by intruding the relevant principle in sustainable energy technology agenda and strategies. For instance, the sector needs an effective asset management plan such as transforming into advanced connected decentralized wastewater treatment plant instead scattered treatment plant and individual septic tank to reduce their losses and to meet the increasing demand in coming years (May Lim et al., 2013; Akademi Sains Malaysia, 2015).

\section{CONCLUSION \& FURTHER RESEARCH}

The paper showcases the contribution of CE to sustainable energy development and its link to the five elements of the QH. In the context of energy sustainability, resource efficiency underscores the execution of actions to enhance transition towards a CE model. The analytical review divulges the importance of QH elements in supporting this transition, underpinning by actions from industry, academia, government, and society for the implementation of sustainable energy technology. In the case of sludge waste management from sewerage, efforts have been mainly oriented to obtain direct benefits through recovered resources from the sludge waste. This model efficiently exploited the resources and byproducts, which presents an economically attractive case for adopting CE pathways in wastewater management. Intervention is needed to focus on changing production patterns and improving resource management towards environmental sustainability. A proactive approach and leadership from the internal (i.e., industries, treatment facilities, utilities, environmental awareness, etc.) and external (i.e., government, academia, and societies) sector are essential for a thriving intervention sector.

One of the significant roles of the government is to provide financial support and land resources and create a CE enabling environment. The Malaysian government has been sustaining significant expenditures in river restoration, water augmentation, and irrigation facilities. These expenditures could be partially reduced by utilizing sludge waste as fertilizers for landscaping or biofuel. Thus, there is a major driving force for holistic sludge waste management. Based on the research findings, it is strongly recommended that the local government and utility providers in different states work collectively to integrate strategic planning and its implementations. To this end, the concept of industrial symbiosis and public-private partnerships would improve the efficiency of resource utilization and solves environmental issues among industries; through the exchange of raw materials, designing of products and services, and well as extending the resource value by converting the sludge waste into high-value products (i.e. biogas, bricks, biochar, etc.).

It has been recognized that public funding in the water supply sector needed to be supplemented by private investments. In Korea, for instance, a private partnership under the BOOT mechanism makes the water sector more appealing for investment opportunities, as the government subsidies focus on meeting the private-sector requirement. In the CE concept, cost recovery is not regarded as the primary objective but rather for pollution management and water augmentation. The wastewater regulations in Malaysia require wastewater treatment to comply with a particular specification level before discharging into rivers, trailed by pollution monitoring at sludge disposal sites, which accounted for a substantial operational cost. Currently, the sewerage cost in Malaysia is highly subsided by the government and 
among the lowest in the world. In moving towards circular economy transition, the existing subsidy for consumer sewerage could be relocated to recover operational expenses, benefiting sludge waste treatment in exploiting renewable energy and efficient technology.

In term of successful institutional frameworks, a blended finance model of sharing equal risks under B0OT mode could boost public-private partnerships. It is apparent in Korea that wastewater management requires long-term investments to provide multiple benefits in the long run. Due to the limited financial resources, it is difficult for local governments to tackle the massive challenge of wastewater management for the entire city at once. Instead, as the first phase, local governments could introduce decentralized wastewater treatment with the support of the private sector and other relevant stakeholders. This would require various stakeholders engagement, including non-governmental organizations (NGOs), industries, and financial institutions. The NGOs could influence society at large through awareness program on the sludge-related impact on health and the benefits of considering the circular economy. While the government can contribute to constructing socially acceptable circular economy solutions, certification, and authorization, the industry can support devising technological interventions. Financial institutions can support the initiatives by providing long-term capital. In the context of technological intervention, the changing role of academia from merely research universities to a more entrepreneurial stance is also important in translating knowledge produced within the university into economic and social efficacy. The collaboration with academia can increase confrontation with industry and society to address the sustainability issues and work towards viable technological solutions.

To conclude, the framework relating the $\mathrm{QH}$ elements with CE proposed in this study has indicated a more collaborative economy that contributes significantly to sustainable energy. As the current research only uncovers the rationales between $\mathrm{QH}$ and CE initiatives, further investigation should be carried out in exploring the impact of each QH elements and provide an empirical analysis of the execution of the suggestions associated with CE and sustainable energy policies. Finally, we hope that this paper will inspire future research to address other resource-intensive sectors and support resource efficiency measures in other sectors.

\section{ACKNOWLEDGEMENTS}

The authors would like to acknowledge Universiti Tenaga Nasional (UNITEN) for the support under Chair in Energy Economics Fund (2019002KETST).

\section{REFERENCES}

Abbas, A. H. et al. (2011) 'Characterization of Malaysian domestic sewage sludge for conversion into fuels for energy recovery plants', 2011 National Postgraduate Conference - Energy and Sustainability: Exploring the Innovative Minds, NPC 2011, pp. 1-4. doi: 10.1109/NatPC.2011.6136402.

Abd, W., Wan, R. and Presenter, A. (2011) 'AN OVERVIEW OF MALAYSIA's SEWERAGE MANAGEMENT MANAGEMENT BACKGROUND OF SEWERAGE MANAGEMENT IN MALAYSIA', (June 1993), pp. 1-15.

Abdullah, W. S. W. et al. (2019) 'The potential and status of renewable energy development in Malaysia', Energies, 12(12). doi: 10.3390/en12122437.

Akademi Sains Malaysia (2015) Study on the Current Issues and Needs for Water Supply and

Wastewater Management in Malaysia. Kuala Lumpur. Available at: https://www.akademisains.gov.my/download/Study on the Current Issues and Needs for Water Supply and Wastewater Management in Malaysia - volume 2.pdf. 
Asia-Pacific Economic Cooperation, (APEC) (2020) 'Circular Economy Roadmap - Malaysia's Practice'. Putraja, Malaysia: Asia-Pacific Economic Cooperation.

Assefa, G. and Frostell, B. (2007) 'Social sustainability and social acceptance in technology assessment: A case study of energy technologies', Technology in Society, 29(1), pp. 63-78. doi: 10.1016/j.techsoc.2006.10.007.

Bergquist, A. K. and Söderholm, K. (2016) 'Sustainable energy transition: the case of the Swedish pulp and paper industry 1973-1990', Energy Efficiency, 9(5), pp. 1179-1192. doi: 10.1007/s12053-0159416-5.

Carayannis, E. G. et al. (2018) 'The ecosystem as helix: an exploratory theory-building study of regional co-opetitive entrepreneurial ecosystems as Quadruple/Quintuple Helix Innovation Models', R and D Management, 48(1), pp. 148-162. doi: 10.1111/radm.12300.

Carayannis, E. G., Barth, T. D. and Campbell, D. F. (2012) 'The Quintuple Helix innovation model: global warming as a challenge and driver for innovation', Journal of Innovation and Entrepreneurship, 1(1), p. 2. doi: 10.1186/2192-5372-1-2.

Carayannis, E. G. and Campbell, D. F. J. (2009) "Mode 3" and "Quadruple Helix": Toward a 21st century fractal innovation ecosystem', International Journal of Technology Management, 46(3-4), pp. 201-234. doi: 10.1504/ijtm.2009.023374.

Carayannis, E. G. and Campbell, D. F. J. (2010) 'Triple helix, Quadruple helix and Quintuple helix and how do Knowledge, Innovation and the environment relate to Each other? a proposed framework for a trans-disciplinary analysis of sustainable development and social ecology', International Journal of Social Ecology and Sustainable Development, 1(1), pp. 41-69. doi: 10.4018/jsesd.2010010105.

Carayannis, E. G. and Rakhmatullin, R. (2014) 'The Quadruple/Quintuple Innovation Helixes and Smart Specialisation Strategies for Sustainable and Inclusive Growth in Europe and Beyond', Journal of the Knowledge Economy, 5(2), pp. 212-239. doi: 10.1007/s13132-014-0185-8.

Chel, A. and Kaushik, G. (2018) 'Renewable energy technologies for sustainable development of energy efficient building', Alexandria Engineering Journal, 57(2), pp. 655-669. doi: 10.1016/j.aej.2017.02.027.

Chen, B. et al. (2019) 'Pathways for sustainable energy transition', Journal of Cleaner Production, 228, pp. 1564-1571. doi: 10.1016/j.jclepro.2019.04.372.

Chu et al. (2017) '“The path towards sustainable energy."', Nature Materials, 16(1), pp. 16-22. doi: 10.1038/nmat4834.

Crumpton, C. D. et al. (2020) 'Assessing the ASEAN Smart Cities Network (ASCN) via the Quintuple Helix Innovation Framework, with Special Regard to Smart City Discourse, Civil Participation, and Environmental Performance', International Journal of Urban Sustainable Development, 00(00), pp. 1-20. doi: 10.1080/19463138.2020.1827411.

Danilenko, A. and Bahuguna, A. (2016) Korea: A model for development of the water and sanitation sector, The Water Blog. Available at: https://blogs.worldbank.org/water/korea-model-developmentwater-and-sanitation-sector (Accessed: 30 October 2019).

Dominković, D. F. et al. (2018) 'The future of transportation in sustainable energy systems: Opportunities and barriers in a clean energy transition', Renewable and Sustainable Energy Reviews, 82(December 2016), pp. 1823-1838. doi: 10.1016/j.rser.2017.06.117.

Durán-Romero, G. et al. (2020) 'Bridging the gap between circular economy and climate change mitigation policies through eco-innovations and Quintuple Helix Model', Technological Forecasting and Social Change, 160(March), p. 120246. doi: 10.1016/j.techfore.2020.120246. 
Ek, K. (2005) 'Public and private attitudes towards "'green'” electricity: the case of Swedish wind power', Energy Policy, 33, pp. 1677-1689. doi: 10.3386/w15081.

Ellen MacArthur Foundation (EMF) (2016) CIRCULAR ECONOMY IN INDIA: RETHINKING GROWTH FOR LONG-TERM PROSPERITY, Ellen MacArthur Foundation (EMF). New Delhi. doi: 10.1007/978-981-15-1052-6_9.

Erat, S. and Telli, A. (2020) 'Within the global circular economy: A special case of Turkey towards energy transition', MRS Energy \& Sustainability, 7, pp. 1-10. doi: 10.1557/mre.2020.26.

Esa, M. R., Halog, A. and Rigamonti, L. (2017) 'Developing strategies for managing construction and demolition wastes in Malaysia based on the concept of circular economy', Journal of Material Cycles and Waste Management, 19(3), pp. 1144-1154. doi: 10.1007/s10163-016-0516-x.

Etzkowitz, H. and Leydesdorff, L. (1995) 'A Laboratory for Knowledge Based Economic Development', EASST Review, 14(1), pp. 14-19.

Galvao, A. et al. (2019) 'Triple helix and its evolution: a systematic literature review', Journal of Science and Technology Policy Management, 10(3), pp. 812-833. doi: 10.1108/JSTPM-10-2018-0103.

Grundel, I. and Dahlström, M. (2016) 'A Quadruple and Quintuple Helix Approach to Regional Innovation Systems in the Transformation to a Forestry-Based Bioeconomy', Journal of the Knowledge Economy, 7(4), pp. 963-983. doi: 10.1007/s13132-016-0411-7.

Hanum, F. et al. (2019) 'Treatment of Sewage Sludge Using Anaerobic Digestion in Malaysia: Current State and Challenges', Frontiers in Energy Research, 7(March), pp. 1-7. doi: 10.3389/fenrg.2019.00019.

Harwiki, W. and Malet, C. (2020) 'Quintuple helix and innovation on performance of SMEs within ability of SMEs as a mediator variable: A comparative study of creative industry in Indonesia and Spain', Management Science Letters, 10(6), pp. 1389-1400. doi: 10.5267/j.msl.2019.11.018.

Herrador, M., Cho, Y. and Park, P. H. (2020) 'Latest circular economy policy and direction in the Republic of Korea: Room for enhancements', Journal of Cleaner Production, 269, p. 122336. doi: 10.1016/j.jclepro.2020.122336.

Hishammuddin, M. A. H. et al. (2018) 'Circular economy (CE): A framework towards sustainable low carbon development in Pengerang, Johor, Malaysia', Chemical Engineering Transactions, 63(October), pp. 481-486. doi: 10.1016/S0375-6505(99)00041-3.

Höglund, L. and Linton, G. (2018) 'Smart specialization in regional innovation systems: a quadruple helix perspective', R and D Management, 48(1), pp. 60-72. doi: 10.1111/radm.12306.

Hong, J. H. et al. (2019) 'Long-term energy strategy scenarios for South Korea: Transition to a sustainable energy system', Energy Policy, 127(November 2018), pp. 425-437. doi: 10.1016/j.enpol.2018.11.055.

IEA (2019a) Global Energy Review 2019. Paris. Available at: https://www.iea.org/reports/globalenergy-review-2019.

IEA (2019b) World Energy Outlook 2019. Paris. Available at: https://www.iea.org/reports/worldenergy-outlook-2019.

Jin, I. (2016) ‘Circular Economy Policy in Korea Chapter 10 Circular Economy Policy in Korea', ERIA Research Project Report, (December), pp. 2014-44163. Available at: http://www.eria.org/RPR_FY2014_No.44_Chapter_10.pdf.

Kangyin, D. et al. (2016) 'Integrated evaluation of circular economy method for chinese petroleum refining industry', Oxidation Communications 39, No. 4(IV), pp. 3999-4013. 
Khor, C. S. and Lalchand, G. (2014) 'A review on sustainable power generation in Malaysia to 2030: Historical perspective, current assessment, and future strategies', Renewable and Sustainable Energy Reviews, 29, pp. 952-960. doi: 10.1016/j.rser.2013.08.010.

Korhonen, J., Honkasalo, A. and Seppälä, J. (2018) 'Circular Economy: The Concept and its Limitations', Ecological Economics, 143, pp. 37-46. doi: 10.1016/j.ecolecon.2017.06.041.

Kumaran, P. (2016) Food waste co-digestion with sewage sludge - Realizing its potential in Malaysia, World Bioenergy Cogress and Expo. doi: 10.1016/j.jenvman.2012.07.029.

Landsberger, S. (2019) 'The circular economy in China', Beijing Garbage, 7410, pp. 53-76. doi: $10.2307 /$ j.ctvhrcz2t.5.

Lausselet, C. et al. (2017) 'Norwegian Waste-to-Energy: Climate change, circular economy and carbon capture and storage', Resources, Conservation and Recycling, 126(June), pp. 50-61. doi: 10.1016/j.resconrec.2017.07.025.

Lettinga, G., Lens, P. and Zeeman, G. (2001) 'No Environmental protection technologies for sustainable development', in Decentralized sanitation and reuse—concepts, systems and implementation. London, pp. 3-10.

Leydesdorff, L. (2012) 'The Triple Helix, Quadruple Helix, ..., and an N-Tuple of Helices: Explanatory Models for Analyzing the Knowledge-Based Economy?', Journal of the Knowledge Economy, 3(1), pp. 2535. doi: 10.1007/s13132-011-0049-4.

Litardi, I., Fiorani, G. and Bara, L. La (2020) 'The Role of The University for Promoting Sustainability through Third Mission and Quintuple Helix Model: The Case Study of Tor Vergata University of Rome', Management Dynamic in the Knowledge Economy, 8(1), pp. 45-60. doi: 10.2478/mdke-2020-0004.

Lopes de Sousa Jabbour, A. B. et al. (2018) 'Industry 4.0 and the circular economy: a proposed research agenda and original roadmap for sustainable operations', Annals of Operations Research, 270(12), pp. 273-286. doi: 10.1007/s10479-018-2772-8.

$\mathrm{Lu}$, Y. et al. (2020) 'A critical review of sustainable energy policies for the promotion of renewable energy sources', Sustainability (Switzerland), 12(12), pp. 1-30. doi: 10.3390/su12125078.

Luengo-Valderrey, M. J. et al. (2020) 'Analysis of the impact of the triple helix on sustainable innovation targets in Spanish technology companies', Sustainability (Switzerland), 12(8). doi: 10.3390/SU12083274.

MacArthur and Ellen (2013) 'Towards the circular economy.', Journal of Industrial Ecology, 2, pp. 23-44.

May Lim et al. (2013) Sustainability Report 2012-2013: Cleaning The Unseen For A Sustainable Future. Kuala Lumpur.

McCarthy, N. (2016) 'The Countries Winning The Recycling Race', Forbes, 4 March.

Melkonyan, A. et al. (2017) 'Sustainability assessment and climate change resilience in food production and supply', Energy Procedia, 123, pp. 131-138. doi: 10.1016/j.egypro.2017.07.236.

Ministry of Energy, Science, Technology, Environment \& Climate Change, (MESCTECC) (2018) Malaysia's Roadmap Towards Zero Single-Use Plastics 2018-2030, Ministry of Energy, Science, Technology, Environment \& Climate Change, (MESCTECC). doi: 10.4324/9780203984420.

Ministry of Environment, M. (2017) Modernization of Sewerage System in Korea: Histotry of Korea's Sewerage Development. Seoul.

Ministry of Environment and Ministry of Enterprise and Innovation (2020) Sweden transitioning to a circular economy, Press Conference Governement Officrs of Sweden. Sweden. 
Mohd Din, I. A. K. (2010) 'Towards Sustainable Sewerage Background of Sewerage Management in Malaysia', 6th Ministerial Conference on Environment and Development in Asia and the Pacific, (October), p. 34. Available at: http://www.unescap.org/sites/default/files/9. MCKadir-Malaysia.pdf.

Mokhtar, H. (2002) 'Malaysia energy situation. COGEN program phase III. Malaysia: Shah Alam'; Shah Alam, Malaysia: EC-ASEAN COGEN Programme Phase III.

Mustapa, S. I. (2018) 'Efficiency Assessment Of Malaysian Coal-Fired Power Plant: A Circular Economy Perspective', (July), pp. 619-629. doi: 10.15405/epsbs.2018.07.02.66.

Nam, K. J., Hwangbo, S. and Yoo, C. K. (2020) 'A deep learning-based forecasting model for renewable energy scenarios to guide sustainable energy policy: A case study of Korea', Renewable and Sustainable Energy Reviews, 122(March 2019), p. 109725. doi: 10.1016/j.rser.2020.109725.

Neczaj, E. and Grosser, A. (2018) 'Circular Economy in Wastewater Treatment Plant-Challenges and Barriers', Proceedings, 2(11), p. 614. doi: 10.3390/proceedings2110614.

OECD (2017) 'Waste, Materials Management and Circular Economy', in OECD Environmental Performance Reviews: Korea 2017. Paris: OECD Publishing. doi: https://dx.doi.org/10.1787/9789264268265-1-en.

Palanisamy K. and Shamsuddin AH (2013) 'Biogas to Energy Potential from Sewage Treatment Plant in Malaysia'.

Palm, J. (2006) 'Development of sustainable energy systems in Swedish municipalities: A matter of path dependency and power relations', Local Environment, 11(4), pp. 445-457. doi: 10.1080/13549830600785613.

Pan, S. Y. et al. (2015) 'Strategies on implementation of waste-to-energy (WTE) supply chain for circular economy system: a review', Journal of Cleaner Production, 108, pp. 409-421. doi: 10.1016/j.jclepro.2015.06.124.

Priyadarshini, P. and Abhilash, P. C. (2020) 'Circular economy practices within energy and waste management sectors of India: A meta-analysis', Bioresource Technology, 304(November 2019), p. 123018. doi: 10.1016/j.biortech.2020.123018.

Qazi, A. et al. (2019) 'Towards Sustainable Energy: A Systematic Review of Renewable Energy Sources, Technologies, and Public Opinions', IEEE Access, 7, pp. 63837-63851. doi: 10.1109/ACCESS.2019.2906402.

Ramli, N. A. and Abdul Hamid, M. F. (2016) 'Analysis of energy efficiency and energy consumption costs: a case study for regional wastewater treatment plant in Malaysia', Journal of Water Reuse and Desalination, 7(1), pp. 103-110. doi: 10.2166/wrd.2016.196.

Rebitanim, N. Z. et al. (2013) 'Potential applications of wastes from energy generation particularly biochar in Malaysia', Renewable and Sustainable Energy Reviews, 21, pp. 694-702. doi: 10.1016/j.rser.2012.12.051.

Sabeen, A. H. et al. (2018) 'Characteristics of the effluent wastewater in sewage treatment plants of Malaysian Urban Areas', Chemical Engineering Transactions, 63, pp. 691-696. doi: 10.3303/CET1863116.

Shafie, S. M. et al. (2011) 'Current energy usage and sustainable energy in Malaysia: A review', Renewable and Sustainable Energy Reviews, 15(9), pp. 4370-4377. doi: 10.1016/j.rser.2011.07.113.

Stern, N. (2006) 'The economics of climate change: The stern review', The Economics of Climate Change: The Stern Review, 9780521877, pp. 1-692. doi: 10.1017/CB09780511817434.

Stoev, G. (2018) 'Circular economy in the EU-South Korea relations'. Seoul.

Swedish Enterprise (2019) Circular economy for a competitive and sustainable business community in Sweden. 
Swedish Enviromental Protection Agency (2008) 'Wastewater treatment in Sweden', Sustainable Development, pp. 1-8. doi: isbn 978-91-620-8704.

Swedish Gas Technology Ltd (2012) Basic Data on Biogas, SGC. doi: 10.1177/107755877102800212.

Tuan Mat, E. A., Shaari, J. and Kok How, V. (2011) 'Wastewater Production, Treatment, and Use in Malaysia', pp. 1-6.

United Nations Brundtland Commission (1987) Report of the World Commission on Environment and Development: Our Common Future Table, United Nations Brundtland Commission. doi: 10.1080/07488008808408783.

W Muhammad Abdullah, W. M. Z. et al. (2021) 'Public Participation of Renewable Energy ( PPRED ) Model in Malaysia : An Instrument Development', Int. Journal of Renewable Energy Development, 10(1), pp. 119-137. doi: 10.14710/ijred.2021.32311.

Werner, C. et al. (2003) 'Reasons for and principles of ecological sanitation', In IWA 2nd international symposium on ecological sanitation, 7(April), pp. 23-30.

Westblom, C. (2015) 'Towards a Circular Economy in Sweden. Barriers for new business models and the need for policy intervention', (September), p. 99.

Wijkman, A. and Skånberg, K. (2015) 'The Circular Economy and Benefits for Society: Jobs and Climate Clear Winners in an Economy Based on Renewable Energy and Resource Efficiency', The Club of Rome, p. 59. Available at: http://www.clubofrome.org/cms/wp-content/uploads/2015/10/TheCircular-Economy-and-Benefits-for-Society.pdf. 